\title{
COUPLING STUDY OF THE VARIABLE INFILTRATION CAPACITY (VIC) MODEL WITH WEATHER RESEARCH AND FORECASTING (WRF) MODEL TO SIMULATE THE STREAMFLOW IN THE GUADALQUIVIR BASIN
}

\author{
M. GARCÍA-VALDECASAS-OJEDA, S. de FRANCISCIS, S.R. GÁMIZ-FORTIS, \\ Y. CASTRO-DÍEZ and M.J. ESTEBAN-PARRA \\ Applied Physics Department, University of Granada. \\ mgvaldecasas@ugr.es
}

\begin{abstract}
Variable Infiltration Capacity (VIC) model is a large-scale hydrologic model. Land surface is modeled as a grid of large and uniform cells with sub-grid heterogeneity (e.g. land cover), while water influx is local, only depending from the interaction between grid cell and local atmosphere environment. Water streamflow is obtained separately from the land surface simulation, using the Routing Model. The goal of this work consists into set an optimal hydrological and climate model to study the evolution of the streamflow of Guadalquivir Basin, with different future land use, land cover and climate scenarios, implemented with the regional Weather Research and Forecasting (WRF) model. In this work we present some results concerning the calibration of the most relevant parameters of VIC model, comparing the streamflow simulations obtained from the observational climate data SPAIN02 and WRF otuputs databases, with the use of observational reservoirs and gauging stations daily streamflow time series, obtained from CEDEX database, in the time period 1988-1997.
\end{abstract}

Key words: Hydrological model, Guadalquivir streamflow, WRF model, VIC model.

\section{RESUMEN}

El modelo Variable Infiltration Capacity (VIC) es un modelo hidrológico de gran escala. La superficie terrestre es modelada considerando una gran rejilla de celdas uniformes que presentan heterogeneidad a escala de sub-rejilla (esto es, cubierta superficial), mientras que el flujo de agua es local, únicamente dependiente de la interacción entre celdas y el medio ambiente local. El caudal de agua se obtiene separadamente a partir de la simulación de la superficie terrestre usando el denominado modelo Routing. El objetivo de este trabajo consiste en calibrar un modelo hidrológico y climático de forma óptima con el fin de estudiar la evolución del caudal en la Cuenca del Guadalquivir, con diferentes posibles usos del suelo futuros, cobertura superficial y escenarios climáticos, implementado con el modelo regional Weather Research and Forecasting (WRF). En este trabajo se presentan resultados relativos a la calibración de los parámetros más relevantes del modelo VIC, comparando las simulaciones de caudal obtenidas por el mismo a partir de los datos climáticos observacionales de 
SPAIN02 y de las salidas del modelo WRF, con los datos de caudal diario observacionales del CEDEX, para el periodo 1988-1997.

Palabras clave: Modelo hidrológico, caudal del Guadalquivir, modelo WRF, modelo VIC.

\section{INTRODUCTION}

Water plays a determinant role in the behavior of climate systems, because of the dependence of human activities on hydric resources. Studies of the alterations in hydrological cycles under the effect of climate change are very relevant in order to understand the anthropic effect on the climate and to evaluate their impacts at regional scale, involving many aspects of human welfare, from agricultural productivity to energy use, flood control, urban and industrial water supply and fisheries, flora and fauna management.

Water resources in the Iberian Peninsula, and particularly in Andalusia, have a considerable interest because of the large annual variability of temperature and precipitation in this region (Serrano et al., 1999), with marked periods of drought. Moreover, there is an over-exploitation of water resources due to an increase in demand for water for agriculture, industry and tourism (Garrido and Gómez-Ramos, 2000). In fact, it has been shown that under a scenario of global warming, southern and western Europe could experience a decrease in agriculture yields of about $25 \%$ (PESETA project, 2009).

Streamflow variability plays an important role in the development and management of water resources in most regions of the world. In the last IPCC report it was stated that the entire Mediterranean region (including the Iberian sector) is currently presenting a broadly consistent decline in precipitation and flow rates (IPCC, 2013). The hydrological system acts as a spatial and temporal integrator of primary climate variables such as precipitation, temperature and evapotranspiration on a specific region, so the seasonal and annual streamflow variability in many basins is controlled by large-scale changes in atmospheric circulation patterns (Gámiz-Fortis et al., 2008). The relationship between these climatic regimes and hydrological response has different degrees of complexity depending on the physical characteristics of the basin, integrating the climate forcings mentioned before. Additionally, the streamflow comes from naturally filtered precipitation, making it less prone to spatial and temporal noise effect (Gámiz-Fortis et al., 2008). This justifies that studies about hydrological impacts of climate change should consider mainly the analysis of secondary variables such as river flows (Boé et al., 2007).

The ultimate goal of our research line consists in the estimation of the projected Guadalquivir Basin streamflow by applying a hydrologic model that employs the input variables obtained from the climate change outputs projected by a regional model under different climate change scenarios.

For this purpose, we adopt the VIC hydrological model (http://vic.readthedocs.io/

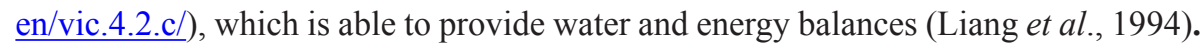




\section{METHODS}

VIC model is a large-scale hydrologic model, where land surface is modeled as a grid of large and uniform cells with sub-grid heterogeneity, e.g. land cover.

The variability of land cover is represented by a classification of the grid cells according to types of vegetation or bare soil, and the soil layer is divided into three levels. Saturation excess resulting from runoff currents is parameterized through the variable infiltration curve provided by the Xinanjiang model (Wood et al., 1992).

Grid cells have here a spatial resolution of $10 \mathrm{~km}$, with daily input/output temporal resolutions. The minimum meteorological forcing input data required by the model are daily precipitation and daily maximum and minimum temperatures. Other variables that can be further supplied to the model input are surface albedo, longwave and shortwave radiation, specific humidity, zonal and meridional wind components, and/or atmospheric pressure. When these input variables are not provided, the model uses different calculation algorithms from the minimum variables required. Evapotranspiration is calculated using a modification of the Penman-Monteith equation (Shuttleworth, 1993) which allows the net radiation and other heat fluxes vary throughout the day.

The great computational performance of VIC model is due to the local water/ energy influxes, i.e. they only depend from the interaction between soil and vegetation in the single grid cell and local atmosphere environment. In this way, each cell is an isolated system, whose dynamic is independent to the rest of the system. The main outputs of VIC, water runoff and baseflow, are used as the inputs for a spatial network based model, the Routing model (Lohmann et al., 1998). In such a model the daily grid cell runoff/base flow are routed to the edges of grid cell, through the river network (defined by using the slopes in the elevation map), and finally reaching the observation point. The resulted hydrographs of routed daily flows can be then compared to the historical observational data.

\subsection{Implementation of VIC model: input database}

In order to run VIC, several sets of input data are necessary:

Soil Parameter File, composed by cell ID numbers, latitude/longitude, soil texture and other characteristics. We made use of the ISRIC-World Soil Information database (http://soilgrids $1 \mathrm{~km}$.isric.org) to extract information on soil composition, i.e. bulk density, sand percent and clay percent. From these 3 quantities in union with the USGS digital elevation map (https://lta.cr.usgs.gov/HYDRO1K) and the average annual precipitation (calculated from SPAIN02 database, http://www.meteo. unican. es/en/datasets/spain02) we originated all the necessary variables to build the soil parameter file, e.g. field capacity, saturated hydrological conductivity, and wilting point. We chose to edit the soil file with 3 layers, initially set with width $[0,-0.15 \mathrm{~m}]$, $[-0.15,-0.6 \mathrm{~m}]$, and $[-0.6,-2.0 \mathrm{~m}]$.

Vegetation Library File, which describes the available land cover types, and Vegetation Parameter File, which describes the land cover types and their properties, fractional areas, rooting depths, and seasonal leaf area index (LAIs) of the various land cover tiles within each grid cell. Vegetation library file is built from the re-gridding 
of the NASA LDAS (Land Data Assimilation System) database (1das.gsfc.nasa.gov/ gldas/GLDASvegetation GLDAS1.php), while the parameter file is the same used in NOAH Land Surface Model, downloadable from University Corporation for Atmospheric Research (UCAR)-National Center for Atmospheric Research (NCAR) (www.ral.ucar.edu/research/land/technology/lsm.php).

Meteorological Forcing Files. VIC takes daily time series of meteorological variables as inputs: precipitation, air temperature, wind speed, atmospheric pressure and density, vapor pressure (or vapor pressure deficit or relative humidity or specific humidity), incoming shortwave (solar) radiation, and incoming longwave (or thermal) radiation. However, VIC can estimate some of these quantities internally, so that the user need not supply all of them. The minimum set of variables that VIC requires are: daily total precipitation, and daily maximum and minimum temperatures.

\subsection{VIC calibration algorithm and routine}

VIC model has more than 20 parameters to be specified. Usually the calibration process consists in adjusting six of them (Nijssen et al., 1997):

a) $b$ inf $-[>0$ to $\sim 0.4]$. This parameter defines the shape of the Variable Infiltration Capacity curve. It describes the amount of available infiltration capacity as a function of relative saturated grid cell area. A higher value of $b$ inf gives lower infiltration and yields higher surface runoff. The infiltration parameter controls the transformation of rain (or snowmelt) in infiltration and direct runoff.

b) Soil Depth layers 2 and 3, D2 and D3 - [typically from 0.1 to 1.5 meters]. Soil depth affects many model variables. In general, for runoff considerations, thicker soil depths slow down (baseflow dominated) seasonal peak flows and increase the loss due to evapotranspiration. The depth of the topsoil (D1) is usually specified a priori.

c) Baseflow parameters: baseflow (Dsmax) fraction of the maximum speed of the baseflow (Ds), and fraction of the maximum moisture content of soil in the third layer (Ws). These three parameters determine how quickly the water stored in the third layer of soil is evacuated as a baseflow (Liang et al., 1994). Dsmax is calculated from the slope of elevation map.

c.1) Ds - [>0 to 1]. This is the fraction of Dsmax where non-linear (rapidly increasing) baseflow begins. With a higher value of Ds, the baseflow will be higher at lower water content in lowest soil layer.

c.2) Ws - [ $>0$ to 1]. This is the fraction of the maximum soil moisture (of the lowest soil layer) where non-linear baseflow occurs. This is analogous to Ds. A higher value of Ws will raise the water content required for rapidly increasing, non-linear baseflow, which will tend to delay runoff peaks.

The model is calibrated similar to that described in Hurkmans et al. (2008). The parameters b_inf, D2, D3, Ds and Ws are calibrated using the SCE-UA algorithm shuffled complex evolution method developed at the University of Arizona (Duan et al., 1994), with Nash-Sutcliffe efficiency as objective function (Hurkmans et al. 2009). This calibration is carried out for different areas or subareas separately, taking into account topographical, lithological and climatological criteria. Thus, a priori, in the 
Guadalquivir Basin we distinguish between two sub-basins in high Guadalquivir River, two sub-basins corresponding to middle Guadalquivir and Genil sub-basins, one more in the low Guadalquivir, and the last one including the river mouth, see Figure 1.

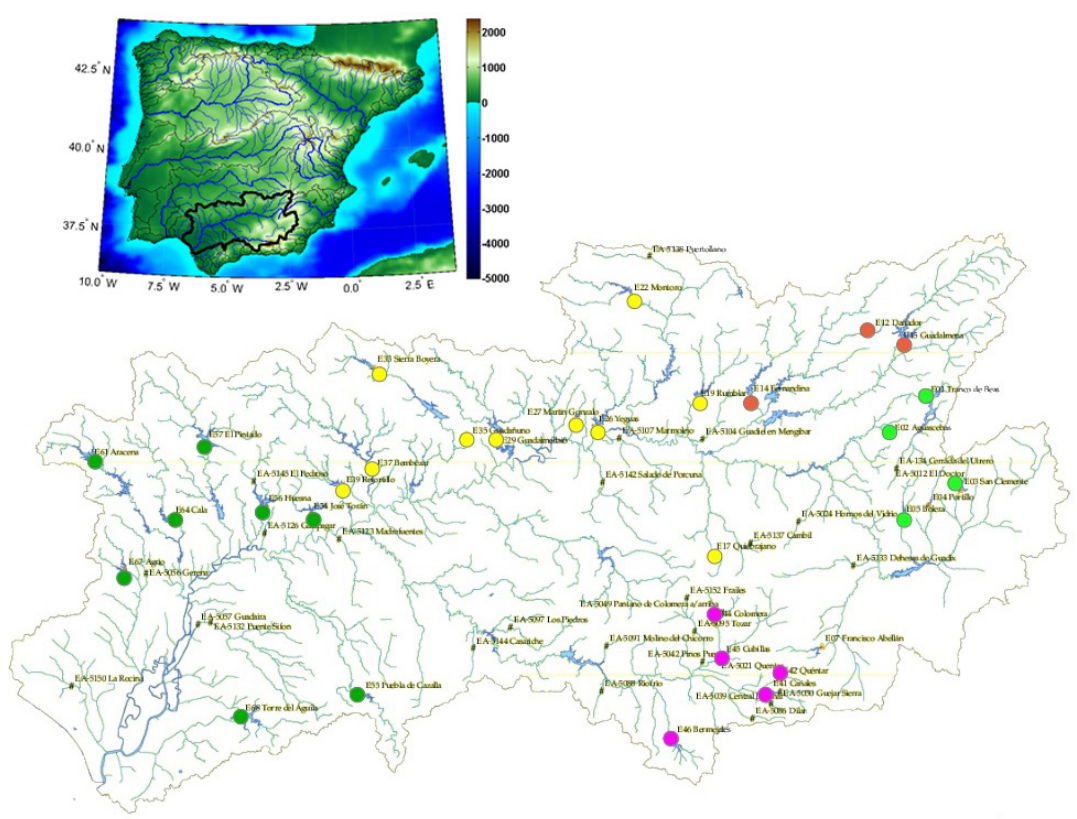

Figure 1: (up) Location of Guadalquivir Basin in the Iberian Peninsula. (bottom) Headwater reservoirs included in the CEDEX database. Colors corresponds to the reservoirs located in the different sub-basins: I-clear green and II-orange in the high Guadalquivir, III-yellow in the middle Guadalquivir, IV-violet for the Genil and V-dark green in the low Guadalquivir and river mouth.

\section{VIC CALIBRATION STEP}

Because the calibration process is computationally very demanding, the model was calibrated in a relatively short period: 1988-1997. The minimum set of forcing meteorological input used (daily total precipitation, daily maximum and minimum temperature) has been obtained from SPAIN02 database. In this time period, the SCE-UA algorithm compares the Routing model output streamflows with the daily time series of the observational headwater reservoir stations obtained from the Development Center for Hydrographic Studies (CEDEX, http://ceh-flumen64.cedex.es/anuarioaforos/ default.asp, Figure 1), by means of the opposite Nash-Sutcliffe efficiency objective function:

$$
E=\frac{\sum_{i=1}^{N}\left(Q_{r u n, i}-Q_{o b s, i}\right)^{2}}{\sum_{i=1}^{N}\left(Q_{o b s, i}-\left\langle Q_{o b s}\right\rangle\right)^{2}}-1
$$


where $Q_{\text {run }, i}$ and $Q_{\text {obs }, i}$ are the temporal datasets of simulated and observed streamflow at time $i$. Nash-Sutcliffe efficiency can range from -1 to $\infty$. An efficiency of -1 corresponds to a perfect match of modeled discharge to the observed data. An efficiency of 0 indicates that the model predictions are as accurate as the mean of the observed data; whereas an efficiency more than zero $(E>0)$ occurs when the observed mean is a better predictor than the model or, in other words, when the residual variance (described by the numerator in the expression above), is larger than the data variance (described by the denominator). Essentially, the closer the model efficiency is to -1 , the more accurate the model is. The efficiency coefficient is sensitive to extreme values and might yield sub-optimal results when the dataset contains large outliers in it (Nash and Sutcliffe, 1970).

In Table 1 we compare the Nash-Sutcliffe objective function in the case of VIC with calibrated (b_inf, D2, D3, Ds, Ws) in 6 sub-basins sets [E(B)] and with the suggested initial parameters set (b_inf, D2, D3, Ds, Ws) $=(0.2,0.45,1.4,0.001,0.9)$ $[\mathrm{E}(\mathrm{O})]$, by the original VIC manual. Optimized VIC improves the adjust to observational data. In fact, the number of reservoir stations that improve their objective function, i.e. where $\mathrm{E}(\mathrm{B})<\mathrm{E}(\mathrm{O})$, or such that $\mathrm{E}(\mathrm{B})$ deviates from $\mathrm{E}(\mathrm{O})$ less than 0.1 , are $26 / 31(83 \%)$. In addition, the number of reservoir stations with $\mathrm{E}(\mathrm{B})<0.07$ (Hurkmans et al., 2009) are 19/31 (61\%).

\begin{tabular}{|c|c|c|c|c|c|c|c|}
\hline \#Station & $\begin{array}{l}\text { Initial } \\
\text { set (0) }\end{array}$ & $\begin{array}{l}\text { Opt. } \\
\text { set (B) }\end{array}$ & $\mathbf{E}(0)-E(B)$ & \#Station & $\begin{array}{l}\text { Initial } \\
\text { set (0) }\end{array}$ & $\begin{array}{l}\text { Opt. } \\
\text { set (B) }\end{array}$ & $\mathbf{E}(0)-\mathrm{E}(\mathrm{B})$ \\
\hline Sub-basin 1 & & & & Sub-basin 4 & & & \\
\hline 5001 & 0,110 & 0,113 & $-0,003$ & 5020 & $-0,366$ & $-0,471$ & 0,104 \\
\hline 5029 & 0,049 & 0,059 & $-0,010$ & 5021 & $-0,185$ & $-0,377$ & 0,192 \\
\hline 5045 & $-0,575$ & $-0,574$ & $-0,001$ & 5038 & $-0,038$ & $-0,392$ & 0,355 \\
\hline 5060 & $-0,483$ & $-0,397$ & $-0,086$ & 5048 & 0,573 & 0,394 & 0,179 \\
\hline Sub-basin 2 & & & & 5050 & $-0,078$ & $-0,032$ & $-0,047$ \\
\hline 5018 & $-0,431$ & $-0,479$ & 0,048 & Sub-basin 5 & & & \\
\hline 5044 & $-0,424$ & $-0,430$ & 0,006 & 5011 & $-0,009$ & $-0,139$ & 0,130 \\
\hline 5052 & $-0,011$ & 0,029 & $-0,040$ & 5014 & $-0,034$ & $-0,201$ & 0,167 \\
\hline Sub-basin 3 & & & & 5016 & $-0,066$ & $-0,348$ & 0,282 \\
\hline 5005 & 0,009 & 0,030 & $-0,021$ & 5022 & $-0,079$ & $-0,276$ & 0,197 \\
\hline 5006 & \begin{tabular}{|l|}
$-0,159$ \\
\end{tabular} & $-0,035$ & $-0,123$ & 5055 & $-0,439$ & $-0,567$ & 0,128 \\
\hline 5012 & $-0,048$ & 0,004 & $-0,052$ & 5056 & 4,914 & 45,677 & $-40,763$ \\
\hline 5017 & $-0,058$ & 0,007 & $-0,065$ & 5061 & $-0,081$ & $-0,373$ & 0,292 \\
\hline 5037 & $-0,100$ & $-0,251$ & $-0,075$ & 5058 & $-0,323$ & $-0,690$ & 0,367 \\
\hline 5039 & $-0,538$ & $-0,366$ & $-0,172$ & & & & \\
\hline 5046 & 6,998 & $-0,072$ & 7,070 & & & & \\
\hline 5047 & $-0,453$ & \begin{tabular}{|l|}
$-0,190$ \\
\end{tabular} & $-0,263$ & & & & \\
\hline 5049 & $-0,502$ & $-0,345$ & $-0,157$ & & & & \\
\hline 5052 & $-0,011$ & $-0,004$ & $-0,007$ & & & & \\
\hline 5062 & $-0,102$ & \begin{tabular}{|c|}
$-0,394$ \\
\end{tabular} & 0,293 & & & & \\
\hline
\end{tabular}

Table 1: Nash-Sutcliffe objective function for VIC calibrated parameters, E(B), and with the initial set, $E(O)$. 
In Figure 2 some typical examples of streamflow outputs obtained from calibrated VIC compared with observational data are shown. As it can be seen, streamflows are accurately reproduced, although the very extreme high values tend to be subestimated by the model.

\section{ROBUSTNESS ANALYSIS FOR WRF VARIABLES}

Once we obtained the calibration of VIC, we test the robustness of the model and/ or the goodness of Weather Research and Forecasting (WRF) model, by replacing or adding in the previously optimized VIC new meteorological input variables obtained by WRF model. We run the configurations with just one WRF variable (wind intensity and direction, shortwave radiation, specific humidity, atmospheric pressure) added to the SPAIN02 (precipitation, Tmax, Tmin) set (SPAIN02+X), and finally with adding all the new aforementioned WRF variables (SPAIN02+ALL).
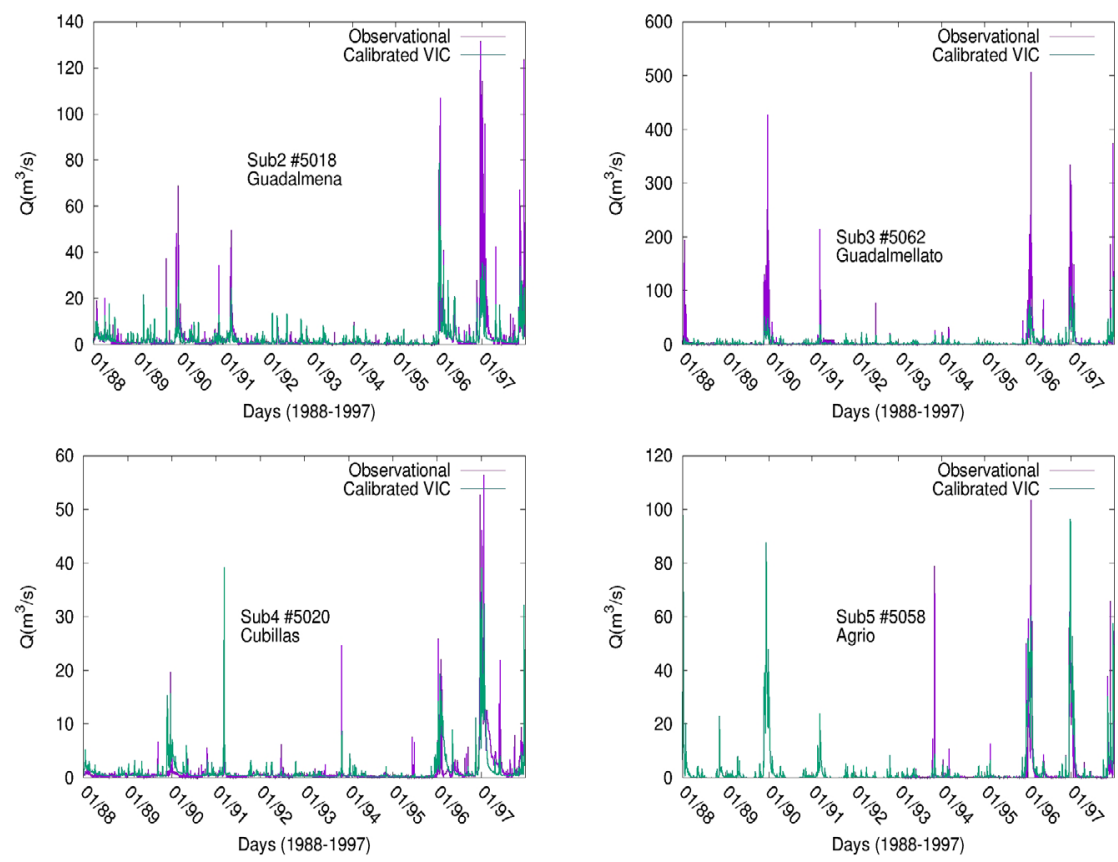

Figure 2: Some examples of streamflow outputs obtained from calibrated VIC (green) compared with observational data (violet).

Our analysis is focused on the evaluation, for each reservoir stations, of temporally "local" and "global" statistical observables, i.e. the Nash-Sutcliffe efficiency $(E)$, the Relative Volume Error $(R V E)$, the relative Root Mean Square Error $\left(R M S E_{r e l}\right)$, defined as:

$$
R V E=\frac{\left\langle Q_{r u n}\right\rangle-\left\langle Q_{o b s}\right\rangle}{\left\langle Q_{o b s}\right\rangle} \quad R M S E_{r e l}=\frac{\sqrt{\sum\left(Q_{r u n, i}-Q_{o b s, i}\right)^{2}} / N}{\left\langle Q_{o b s}\right\rangle}
$$


For SPAIN02+WIND, RAD and HUM configurations the values of $E, R V E$ and $R M S E_{\text {rel }}$ observables are improved, with respect to SPAIN02 case, in a number of reservoir stations from $19 / 30(63 \%)$ to $22 / 30(73 \%)$. In addition for all the statistical observables, there is a fixed set of 8 reservoir stations that worsen their value, all corresponding to the best ones calibrated.

Concerning atmospheric pressure, it seems to have a poor role in streamflows dynamic. For this case, $E, R V E$ and $R M S E_{\text {rel }}$ values show (positive or negative) variations just in $6 / 30(20 \%)$ of reservoir stations.

Analysis of the relative variation of observables $f$,

$$
\operatorname{Var}(f, X)=\frac{f(\text { SPAINO2 })-f(\text { SPAINO2 }+X)}{f(\text { SPAINO2 })}
$$

indicates that in all configurations there are a precise amount of the WRF meteorological variables concerning their strength of influence in the streamflow profiles, so that:

$$
\begin{gathered}
\operatorname{Var}(E, A L L)>\operatorname{Var}(E, W I N D)>\operatorname{Var}(E, R A D)>\operatorname{Var}(E, H U M) \\
\operatorname{Var}(R V E, A L L)>\operatorname{Var}(R V E, W I N D)>\operatorname{Var}(R V E, R A D)>\operatorname{Var}(R V E, H U M) \\
\operatorname{Var}\left(R M S E_{r e l}, A L L\right)>\operatorname{Var}\left(R M S E_{r e l}, W I N D\right)>\operatorname{Var}\left(R M S E_{r e l}, R A D\right)>\operatorname{Var}\left(R M S E_{\text {rel }}, H U M\right)
\end{gathered}
$$

\begin{tabular}{|c|c|c|c|c|}
\hline \#Station & $\begin{array}{c}\text { Meteorological } \\
\text { Input (SPAIN02+X) }\end{array}$ & $\begin{array}{c}\operatorname{Var}(E, X) \\
(\%)\end{array}$ & $\begin{array}{c}\operatorname{Var}(R V E, X) \\
(\%)\end{array}$ & $\begin{array}{c}\operatorname{Var}\left(\boldsymbol{R M S E} E_{r e l}, X\right) \\
(\%)\end{array}$ \\
\hline \multirow[t]{5}{*}{$\# 5020$} & SPAIN02+ALL & $-2,523$ & $-5,906$ & $-0,801$ \\
\hline & SPAIN02+WIND & $-0,969$ & $-2,926$ & $-0,364$ \\
\hline & SPAIN02+RAD & $-0,457$ & $-2,064$ & $-0,186$ \\
\hline & SPAIN02+HUM & $-0,188$ & $-0,947$ & $-0,081$ \\
\hline & SPAIN02+PRE & 0,000 & 0,000 & 0,000 \\
\hline \multirow[t]{5}{*}{ \#5017 } & SPAIN02+ALL & 4,627 & 0,042 & 0,016 \\
\hline & SPAIN02+WIND & 1,931 & 0,013 & 0,007 \\
\hline & SPAIN02+RAD & 1,096 & 0,008 & 0,004 \\
\hline & SPAIN02+HUM & 0,223 & 0,001 & 0,001 \\
\hline & SPAIN02+PRE & 0,000 & 0,000 & 0,000 \\
\hline
\end{tabular}

as it is shown in Table 2 for two chosen stations, with negative and positive variations, respectively.

Table 2: Relative variations in Nash-Sutcliffe efficiency (E), Relative Volume Error (RVE), and Relative Root Mean Square Error (RMSE ${ }_{\text {rel }}$ ), between the simulated streamflows using different meteorological input variables $(X)$ added to SPAIN02.

We attempt to explain the origin of such variation with the introduction of new WRF variables in the following way: original SPAIN02 output in general overestimates the null or almost null streamflow periods, while it underestimates the streamflow 
peaks; each WRF variable increases the streamflow output with different strength, and with an accumulative effect, i.e. SPAIN02 $+A L L$ has always a greater effect than a single WRF variable, so that the positive or negative percentage of variation depends on the predomination of low activity period or peaks in the observational series. Figure 3 shows some samples of this behavior for two of the best calibrated stations.
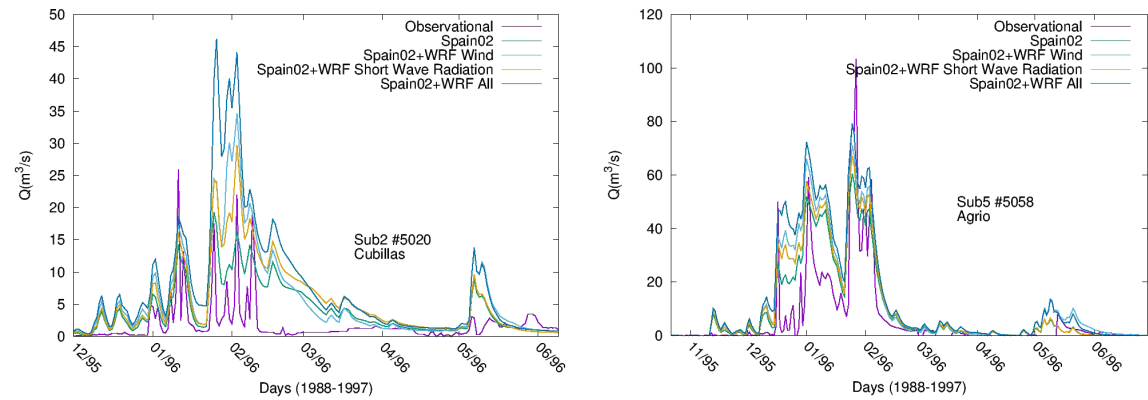

Figure 3: Example of the streamflow change in VIC model with the introduction of WRF variables for the reservoir stations $\# 5020$ and $\# 5058$

\section{CONCLUSION}

This work about Guadalquivir Basin streamflow shows that calibration of hydrological VIC model with the use of CEDEX historical observational reservoir data seems to be good enough compared with other studies about the VIC calibration for other basins (Hurkmans et al., 2009). Moreover, it is important to consider the long observational period used, 1988-1997, and the joint optimization of several reservoirs datasets for each one of sub-basins, differently from several past works (Hurkmans et al., 2008, 2009). Analysis of outputs with the addition of some WRF variables demonstrates the important role played by wind direction and speed as well as shortwave radiation. Thus, in future works will be relevant to include these variables in the calibration process, as far as possible extracted from robust observational data.

Recent works (Hurkmans et al., 2009, 2010) have shown the greatest ability of this model to properly reproduce both the average and extreme streamflows compared to other models, and also its adequate use in climate impact assessment. VIC is less sensitive to parameter settings than the simpler water balance models (Hurkmans et al., 2008). This is an important advantage, since it is questionable whether the parameters of certain conceptual models under current climatic conditions will be valid throughout the XXI century under a changing climate. So, VIC could be a valuable tool to study the climate change impacts on water resources.

\section{AKNOWLEDGEMENTS}

The analysis was carried out in the ALHAMBRA computer infrastructure (https:// alhambra.ugr.es) at the University of Granada. This work has been financed by the projects P11-RNM-7941 (Junta de Andalucía-Spain) and CGL2013-48539-R (MINECO-Spain, FEDER). 


\section{REFERENCES}

Boé, J., Terray, L., Habets, F. and Martin, E. (2007). Statistical and dynamical downscaling of the Seine basin climate for hydro-meteorological studies. International Journal of Climatology., 27, 1643-1655.

Ciscar, J.C., Iglesias, A., Feyen, L., Goodess, C.M., Szabó, L., Christensen, O.B., Nicholls, R., Amelung, B., Watkiss, P., Bosello, F., Dankers, R., Garrote, L., Hunt, A., Horrocks, L., Moneo, M., Moreno, A., Pye, S., Quiroga, S., van Regemorter, D., Richards, J., Roson, R., Soria, A. (2009). Climate change impacts in Europe. Final report of the PESETA research project.

Duan, Q., Sorooshian, S., and Gupta, V.K. (1994). Optimal use of the SCE-UA global optimization method for calibrating watershed models, Journal of Hydrology, 158 (3), 265-284.

Garrido, A. and Gómez-Ramos, A. (2000). Socio-economic aspects of droughts. In Drought and Drought Mitigation in Europe. Advances in Natural and Technological Hazards Research. Vogt, J.V., Somma, F. (eds.), Kluwer Academic Publishers, 14, 197-207.

Gámiz-Fortis SR, Pozo-Vazquez D, Trigo RM and Castro-Díez Y. (2008). Quantifying the predictability of winter river flow in Iberia. Part I: Interannual predictability. Journal of Climate, 21, 2484-2502.

Hurkmans, R.T., de Moel, H., Aerts, J.C., and Troch, P.A. (2008). Water balance versus land surface model in the simulation of Rhine river discharges. Water Resources Research., 44, W01418.

Hurkmans, R.T., Terink, W., Uijlenhoet, R., Moors, E.J., Troch, P.A., and Verburg, P.H. (2009). Effects of land use changes on streamflow generation in the Rhine basin. Water Resources Research 45, W06405.

Hurkmans, R.T0, Terink, W., Uijlenhoet, R., Torfs, P., Jacobs, D., and Troch, P.A. (2010). Changes in streamflow dynamics in the Rhine basin under three highresolution regional climate scenarios, Journal of Climate, 23, 679-799.

IPCC (2013). Climate Change 2013: The Physical Science Basis. Contribution of Working Group I to the Fifth Assessment Report of the Intergovernmental Panel on Climate Change [Stocker, T.F., Qin, D., Plattner, G.-K., Tignor, M., Allen, S.K., Boschung, J., Nauels, A., Xia, Y., Bex V., Midgley, P.M. (eds.)]. Cambridge University Press, Cambridge, United Kingdom, 1535 pp.

Liang, X., Lettenmaier, D.P., Wood, E.F., and Burges, S.J. (1994). A Simple hydrologically Based Model of Land Surface Water and Energy Fluxes for GSMs. Journal of Geophysical Research, 99(D7), 14.415-14.428.

Lohmann D, Raschke E, Nijssen B, Lettenmaier D P. (1998). Regional scale hydrology: I. Formulation of the VIC-2L model coupled to a routing model. Hydrological Science Journal, 43(1), 131-141.

Nash, J.E., and Sutcliffe, J.V. (1970). River flow forecasting through conceptual models part I - A discussion of principles, Journal of Hydrology, 10 (3), 282290. 
Nijssen, B., Lettenmaier, D.P., Liang, X., Wetzel, S.W., and Wood, E.F. (1997). Streamflow simulation for continental-scale river basins. Water Resources Research, 33, 711-724.

Shuttleworth WJ. (1993). Evaporation. Handbook of Hydrology, D.R. Maidment (Ed.), McGraw Hill, 4.2-4.18.

Wood EF, Lettenmaier DP and Zartarian VG. (1992). A land-surface hydrology parameterization with subgrid variability for general circulation models. Journal of Geophysical Research, 97 (D3), 2717-2728. 